\title{
RADIKALISME ISLAM VS MODERASI ISLAM: UPAYA MEMBANGUN WAJAH ISLAM INDONESIA YANG DAMAI
}

\author{
${ }^{1} \mathrm{NURUL}$ FAIQAH, ${ }^{2} \mathrm{TONI}$ PRANSISKA \\ ${ }^{1}$ UIN Sunan Kalijaga Yogyakarta \\ ${ }^{2}$ STAI Sunan Pandanaran Yogyakarta \\ elnury16@gmail.com, tonyelnoory@ymail.com
}

\begin{abstract}
This article explains that all religions strictly prohibit acts of terror that can threaten harmony, wholeness and diversity of the nation. Terrorism and radicalism are not always ideologically motivated, but non-religious factors are dominant such as social, economic, political and others. Therefore, it is necessary to promote and promote a new discourse and paradigm of inclusive and tolerant Islamic understanding of moderation of Islam (wasathiyah al-Islām). The emergence of radical Islamism must immediately be balanced with the vision of moderate Islam. That is the image of Islam that upholds the valuesof moderation, tolerance and equality of rights.Moderation of Islam is a middle ground in the midst of religious diversity. The image of moderation of Islam appears in harmony between Islam and local wisdom. This Local Value as a cultural heritage of the archipelago, can be juxtaposed parallel so that between the spirit of Islam and cultural wisdom goes hand in hand, not mutually negate. This is where the image of Indonesian Islam is considered very appropriately applied in the context of cultural heterogeneity in the ASEAN region and the world.
\end{abstract}

Keyword : Radicalism, Moderation of Islam, Terrorism, Paradigm

\section{PENDAHULUAN}

Fenomena

radikalisme dan terorisme berbasis

agama akhir-akhir ini menjadi keprihatinan kita semua. Baik dalam konteks global maupun indonesia. Dalam sepekan ini Indonesia dihadapkan dengan aksi terror yang simultan. Serangan demi serangan dilancarkan oleh kelompok teroris 
Nurul Faiqah, Toni Pransiska; Radikalisme Islam Vs Moderasi Islam: Upaya Membangun Wajah Islam Indonesia yang Damai.

biadab yang mengancam stabilitas keamanan nasional dan integrasi social. Mulai dari aksi Penyerangan dan Penyanderaan di Mako Brimob (Kompas.com, 11 Mei 2018) hingga aksi bom bunuh diri (suicide bomber) yang terjadi di tiga gereja di Surabaya (news.idntimes.com, 14 Mei 2018). Hingga kabar yang terbaru disusul adanya ledakan bom di rusunawa Sidoarjo (Detik.com, 14 Mei 2018). Aksi teror tersebut hampir selalu memakan korban, baik diri pelakunya maupun warga yang tidak berdosa. $\mathrm{Di}$ samping itu, peristiwa-peristiwa tersebut juga menimbulkan trauma psikologis bagi para korban yang masih hidup dan juga ketakutan di kalangan masyarakat.

Aksi-aksi teror semacam ini bukanlah kali pertamanya terjadi, melainkan aksi tersebut dimulai sejak tiga dekade terakhir di penghujung millenium kedua, tepatnya pertengahan tahun 70-an, masyarakat internasional dikejutkan oleh berbagai tindakan kekerasan, khususnya aksi teror terhadap kepentingan Amerika Serikat dan Israel (Harian al-Ahrām Mesir, 2 Mei 1993). Aksi-aksi tersebut terus meluas seiring dengan datangnya millenium ketiga yang ditandai dengan serangan 11 September 2001 terhadap gedung WTC dan Pentagon. Islam dan umat Islam menjadi pihak yang tertuduh dalam aksi tersebut dan yang sebelumnya dan dianggap sebagai ancaman bagi kehidupan masyarakat dunia. Berbagai stigma pun dilekatkan. Islam identik dengan kekerasan, terorisme, fundamentalisme, radikalisme, dan lain sebagainya. Stigmatisasi ini seakan membenarkan pandangan beberapa pemikir Barat yang berpandangan bahwa Islam merupakan ancaman pasca runtuhnya Soviet, seperti Samuel Huntington dengan tesisnya the clash of civilization.

Dengan mengggalang

kekuatan internasional, Amerika Serikat melancarkan kampanye antiteror. Atas nama itulah, Afganistan dan Irak diserang. Berbagai organisasi dan pergerakan keagamaan juga menjadi sasaran, terutama jaringan Al-Qaeda Internasional. Tuduhan tersebut menemukan relevansinya dengan pernyataan para pelaku yang menyebutkan motivasi keagamaan di balik aksi mereka, sehingga banyak pengamat mengaitkan gerakan islam garis keras dengan terorisme dan kekerasan. Kendati banyak faktor yang melatarbelakanginya seperti politik, ekonomi, sosial, psikologi dan lain sebagainya. Akan tetapi faktor keyakinan dan pemahaman terhadap beberapa doktrin keagamaan agaknya yang paling dominan. Seakan perlawanan menentang hegemoni suatu kekuatan tertentu, yang notabene berbeda agama, dalam berbagai dimensi kehidupan mendapat legitimasi dari teks-teks keagamaan, tentunya dengan pemahaman yang skriptual-literal (nashi), parsial (juz'i) dan ekstrem atau berlebihan (tatharruf/gulwu). Sehingga terkesan konflik bukan lagi karena akumulasi berbagai kekecewaan akibat hegemoni pihak tertentu, tetapi 
seakan meluas kepada konflik agama.

Ibarat tanaman, aksi teror, kekerasan dan radikalisme agama di Indonesia telah menjelma sebagai tanaman yang tumbuh subur. Patah tumbuh, hilang berganti. Agama yang seharusnya menjadi drive atau panduan hidup yang ramah dan toleran justru menjadi pemicu timbulnya kekerasan dan teror. Ini berarti ada kesalahan dalam pemahaman dan implementasi ajaran yang sangat fundamental. Bukankah Islam yang diajarkan oleh Nabi Muhammad justru telah membuktikan sebagai agama yang menjunjung tinggi kasih sayang dan sangat menghargai terhadap perbedaan.

$$
\text { Zuhairi (2009: vii) }
$$

mengungkapkan bahwa terorisme dan radikalisme agama bukan persoalam pelakunya (subjek) bukan pula orang-orang yang menjadi korban dari aksi tersebut (objek). Terorisme dan radikalisme lebih terkait kepada keyakinan teologis. Artinya, pelakunya bisa ditangkap dan dipenjarakan bahkan dibunuh. Tetapi keyakinan dan doktrinnya tidak mudah untuk ditaklukkan. Nah, oleh karena itu, maka perlu mewacanakan dan mempromosikan satu wacana dan paradigma baru tentang pemahaman keislaman yang ramah dan toleran yaitu moderasi islam (wasathiyah al-Islām). Munculnya paham islam radikal harus segera diimbangi dengan visi islam moderat. Yakni Wajah islam yang menjunjung tinggi nilai-nilai moderasi, toleransi dan persamaan hak. Walhasil, kerukunan menjadi keniscayaan bagi bangsa ini. Karena kerukunan merupakan perwujudan kedewasaan berbangsa dan bernegara yang penuh dengan perbedaan (unity in diversity).

\section{RADIKALISME AGAMA: KAJIAN LITERATUR}

Kajian dan penelitian mengenai radikalisme agama sebenarnya telah banyak ditulis dan dikaji oleh para pakar dan peneliti di bidang sosial keagamaan. Sebut saja misalnya buku dengan judul Islam dan Radikalisme Islam di Indonesia yang ditulis oleh Afdhal dkk (2005: 65) dengan pendekatan sosio-politik serta penggalian data yang diambl dari kepustakaan dan penelitian lapangan melalui metode wawancara mendalam terhadap para tokoh baik dari kelompok radikal maupun kelompok fundamentalis non-radikal, yang nisbi maupu yang moderat. Penulisnya mencoba memotret dan mengkaji tentang pemahaman dan pandangan kelompok islam radikal serta berbagai gerakan politik yang dilakukan radikalisme islam di Indonesia kaitannya dalam memperjuangkan berdirinya syariat Islam.

Dalam karyanya Afdhal menemukan fakta bahwa munculnya gerakan radikalisme di Indonesia terkait erat dengan atau dipicu oleh persoalan domestik disamping oleh konstelasi politik internasional yang dinilai telah memojokkan kehidupan sosial politik umat Islam. Berbagai kemelut domestik yang melanda umat islam seperti pembataian kyai dengan berkedok dukun santet, 
Nurul Faiqah, Toni Pransiska; Radikalisme Islam Vs Moderasi Islam: Upaya Membangun Wajah Islam Indonesia yang Damai.

sampai tragedi Poso (1998), tragedi Ambon (1999) di mana umat Islam menjadi korban menurutnya adalah bukti dari penyebab munculnya radikalisme di Indonesia.

$$
\text { Sri Yunanto (2003: 124) }
$$

dalam bukunya Gerakan Militan islam di indonesia dan Asia Tenggara, juga secara fokus mengkaji tentang gerakan islam militan. Dibandingkan kajian tentang gerakan Islam serupa yang lebih cenderung menekankan kepada dimensi sosiologis dan teologis, buku ini lebih memberikan penekanan pada dimensi politik dan keamanan. Untuk dimensi politik yang dikaji dalam buku ini misalkan dapat dicermati dalam kasus-kasus seperti penekanan terhadap gerakan menekan kebijakan implementasi syariat islam, pemberantasan kemungkaran, isu-isu tentang negara islam (al-daulah alislāmiyah), keterkaitan dengan politik militer dan profil organisasi. Sedangkan dimensi keamanan dapat dilihat misalnya dalam kasus keterlibatan kelompok ini dalam konflik di beberapa daerah di Indonesia dan Asia Tenggara dan keterkaitannya dengan isu-isu terorisme.

Genealogi Islam Radikal di Indonesia, ditulis oleh M. Zaki Mubarok (2008: 187) sebuah buku yang memberikan telaah yang cukup komprehensif atas beberapa kelompok yang disebut oleh penulisnya sebagai "Islam Radikal" di Indonesia, segala bentuk sepak terjang dan tujuan yang dikehendaki oleh kelompok Islam Radikal tersebut. Buku ini memberikan gambaran yang cukup gamblang terkait kelompok-kelompok Islam Radikal di Indonesia seperti KISDI (Komite Indonesian untuk Solidaritas Dunia Islam), Laskar Jihad, Forum Pembela islam, dan Majelis Mujahidin.

Benih-benih Islam Radikal di Masjid: Studi Kasus Jakarta dan Solo yang ditulis oleh M. Ridwan alMakasary dan Ahmad Gaus A.F (2009:76) memberikan penjelasan yang sangat "keras" tentang munculnya fenomena bibit-bibit radikalisme di masjid-masjid di Jakarta dan Solo. Penelitian yang dilakukan tersebut memberikan fotret dari mana datangnya bibit radikalisme di mesjid dan dalam kerangka semacam apa radikalisme tersebut terformulasikan. Dengan mengambil beberapa mesjid di Jakarta dan Solo terdapat benang merah yang dapat ditarik di sana. Bahwa radikalisme mesjid tumbuh karena ealogihendak merespon masalah kontemporer. Globalisasi di kalangan masjid yang disinyalir datang dari Barat, bukan dari Islam.

Sebuah artikel dengan judul Radikalisme Islam Klasik dan Komtemporer: Membanding Khawarij dan Hijbut Tahrir yang ditulis oleh Syamsul Rizal (2010: 225-226) Secara khusus, penulis menguji sejauh mana proto-type dan kemiripan karakteristik antara radikalisme Islam klasik, yang diwakili oleh Khawarij, dan radikalisme Islam kontemporer, yang diwakili oleh Hizbut Tahrir. Meskipun tidak ditemukan bukti sejarah yang kuat tentang pengaruh langsung ajaran Khawarij terhadap HT, namun 
penulis berargumentasi bahwa terdapat elemen-elemen Khawarij dalam gerakan Hizbut Tahrir.

Penelitian

tersebut menemukan bahwa adanya beberapa kesamaan karakteristik antara Khawarij dan HT dalam kaitannya dengan ciri radikalisme. Pertama, kedua gerakan tersebut sama-sama muncul sebagai bentuk perlawanan terhadap tatanan social disekitarnya yang tidak disetujuinya. Baik Khawarij maupun HT menggunakan agama sebagai sumber justifikasi untuk melakukan perlawanan. Kedua, Khawarij dan HT cenderung memahami teks-teks Islam secara literal tanpa mengelaborasi konteks, maksud, dan tujuannya. Terakhir, para penganut kedua kelompok tesebut memegang ajarannya masingmasing secara fanatic tanpa kompromi dan dinamika. Walhasil, mereka cenderung menghakimi 'yang lain' sebagai kufur atau tidak faham Islam secara kaffah, serta mengklaim diri (self-claim) sebagai pengemban Islam yang paling benar. Dari eksaminasi singkat ini, penulis menyimpulkan adanya titik singgung (family resemblances) antara radikalisme Islam klasik dan radikalisme Islam kontemporer.

\section{MEMAHAMI TERM RADIKALISME DAN TERORISME}

Istilah radikalisme berasal dari bahasa Latin "radix" yang artinya akar,pangkal, bagian bawah, atau bisa juga berarti menyeluruh, habis-habisan danamat keras untuk menuntut perubahan. Menurut Kamus Besar Bahasa Indonesia
(KBBI) (2008:1151) radikalisme berarti (1) paham atau aliran yang radikal dalam politik; (2)paham atau aliran yang menginginkan perubahan atau pembaharuan sosial danpolitik dengan cara kekerasan atau drastis; (3) sikap ekstrem dalam aliran politik.

Pengertian lain mengungkapkan bahwa yang dimaksud dengan radikal atau radikalisme itu adalah prinsip-prinsip atau praktik-praktik yang dilakukan secara radikal. Suatu pilihan tindakan yang umumnya dilihat dengan mempertentangkan secara tajam antara nilai-niali yang diperjuangkan oleh kelompok (aliran) agama tertentu dengan tatanan nilai yang berlaku atau dipandang mapan pada saat itu (Kemenag, 2014: 3).

Pada dasarnya, perlu dibedakan antara radikal, radikalisme dan radikalisasi. Menurut KH. Hasyim Muzadi, mantan Ketua PBNU dan pengasuh pesantren al-Hikam Malang, pada dasarnya seseorang yang berfikir radikal (berfikir mendalam, sampai ke akar-akarnya) boleh-boleh saja, dan memang berfikir sudah seharusnya seperti itu. Katakanlah misalanya, seseorang yang dalam hatinya berpandangan bahwa Indonesia mengalami banyak masalah (ekonomi, pendidikan, hokum dan politik) disebabkan Indonesia tidak menerapkan syariat Islam, oleh karena itu, misalnya, dasar Negera Indonesia harus diganti dengan system pemerintahan islam (al-khilāfah al-islāmiyah). Pendapat yang radikal seperti itu 
Nurul Faiqah, Toni Pransiska; Radikalisme Islam Vs Moderasi Islam: Upaya Membangun Wajah Islam Indonesia yang Damai.

sah-sah saja. Sekeras apapun pernyataan diatas jika hanya dalam wacana atau pemikiran, tidak akan menjadi persoalan publik. Sebab pada hakikanya, apa yang muncul dal;am benak atau pikiran tidak dapat diadili (kriminalisasi pemikiran) karena tidak termasuk tindak pidana. Kejahatan adalah suatu tindakan (omissi). Dalam pengertian ini, seseorag tidak dapat dihukum hanya karena pikirannya, melainkan harus ada suatu tindakan atau kealpaan dalam bertindak (Abu Rokhmad, 2012: 82).

Adapun term "radikalisme", KH. Hasyim Muzadi mendefinisikannya "radikal dalam paham atau ismenya". Biasanya mereka akan menjadi radikal secara permanen. Radikal sebagai isme ini dapat tumbuh secara demoktratis, force (kekuatan) masyarakat dan teror. Dengan kata lain, radikalisme adalah radikal yang sudah menjadi ideologi dan mazhab pemikiran. Dalam pandangan peneliti, setiap orang berpotensi menjadi radikal dan penganut paham radikal (radikalisme), tergantung apakah lingkungan (habitus) mendukungnya atau tidak.(Kemenag, 2014: 4). Sedangkan yang dimaksud dengan radikalisasi menurut Muzadi adalah (seseorang yang) tumbuh menjadi reaktif ketika terjadi ketidakadilan di masyarakat. Biasanya radikalisasi tumbuh berkaitan dengan ketidakadilan ekonomi, politik, lemahnya penegakan hukum dan seterusnya. Jadi, jangan dibayangkan ketika teroris sudah ditangkap, lalu radikalisme hilang. Sepanjang keadilan dan kemakmuran belum terwujud, radikalisasi akan selalu muncul di masyarakat. Keadilan itu menyangkut banyak aspek, baik aspek hukum, politik, pendidikan, sosial, hak asasi, maupun budaya. Hukum itu berbeda dengan keadilan. Hukum adalah aspek tertentu, sedangkan keadilan adalah akhlak dari hukum itu (Rokhmat, 2012: 83).

Setidaknya, radikalisme bisa dibedakan ke dalam dua level, yaitu levelpemikiran dan level aksi atau tindakan. Pada level pemikiran, radikalisme masihberupa wacana, konsep dan gagasan yang masih diperbincangkan, yang intinyamendukung penggunaan cara-cara kekerasan untuk mencapai tujuan. Adapunpada level aksi atau tindakan, radikalisme bisa berada pada ranah sosial-politikdan agama. Pada ranah politik, faham ini tampak tercermin dari adanya tindakanmemaksakan pendapatnya dengan cara-cara yang inkonstitusional, bahkan bisaberupa tindakan mobilisasi masa untuk kepentingan politik tertentu dan berujungpada konflik sosial.

Dalam bidang keagamaan, fenomena radikalisme agama tercermin daritindakan-tindakan destruktif-anarkis atas nama agama dari sekelompok orangterhadap kelompok pemeluk agama lain (eksternal) atau kelompok seagama(internal) yang berbeda dan dianggap sesat. Termasuk dalam tindakan radikalismeagama adalah aktifitas untuk memaksakan pendapat, keinginan, dan citacitakeagamaan dengan jalan kekerasan. Radikalisme agama bisa 
menjangkiti semua pemeluk agama,tidak terkecuali di kalangan pemeluk Islam.

Lebih detil, Rubaidi (2010: 63) menguraikan lima ciri gerakan radikalisme. Pertama, menjadikan Islam sebagai ideologi final dalam mengatur kehidupan individual dan juga politik ketata negaraan. Kedua, nilai-nilai Islam yang dianut mengadopsi sumbernya-di Timur Tengah—secara apa adanya tanpa mempertimbangkan perkembangan sosial dan politik ketika Al-Quran dan hadits hadir di muka bumi ini, dengan realitas lokal kekinian. Ketiga, karena perhatian lebih terfokus pada teks Al-Qur'an dan hadist, maka purifikasi ini sangat berhati-hati untuk menerima segala budaya non asal Islam (budaya Timur Tengah) termasuk berhati-hati menerima tradisi lokal karena khawatir mencampuri Islam dengan bid'ah. Keempat, menolak ideologi Non-Timur Tengah termasuk ideologi Barat, seperti demokrasi, sekularisme dan liberalisme. Sekali lagi, segala peraturan yang ditetapkan harus merujuk pada AlQur'an dan hadist. Kelima, gerakan kelompok ini sering berseberangan dengan masyarakat luas termasuk pemerintah. Oleh karena itu, terkadang terjadi gesekan ideologis bahkan fisik dengan kelompok lain, termasuk pemerintah.

Peningkatan radikalisme keagamaan banyak berakar pada kenyataan kian merebaknya berbagai penafsiran, pemahaman, aliran, bahkan sekte di dalam (intra) satu agama tertentu. Menurut Azyumardi Azra (2011: 25), di kalangan Islam, radikalisme keagamaan itu banyak bersumber dari:

1. Pemahaman keagamaan yang literal, sepotongsepotong terhadap ayat-ayat al-Qur'an. Pemahaman seperti itu hampir tidak memberikan ruang bagi akomodasi dan kompromi dengan kelompok-kelompok muslim lain yang umumnya moderat, dan karena itu menjadi arus utama (mainstream) umat. Kelompok umat Islam yang berpaham seperti ini sudah muncul sejak masa alKhulafa' al-Rasyidun keempat Ali ibn Abi Thalib dalam bentuk kaum Khawarij yang sangat radikal dan melakukan banyak pembunuhan terhadap pemimpin muslim yang telah mereka nyatakan 'kafir'.

2. Bacaan yang salah terhadap sejarah Islam yang dikombinasikan dengan idealisasi berlebihan terhadap Islam pada masa tertentu. Ini terlihat dalam pandangan dan gerakan Salafi, khususnya pada spektrum sangat radikal seperti Wahabiyah yang muncul di Semenanjung Arabia pada akhir abad 18 awal sampai dengan abad 19 dan terus merebak sampai sekarang ini. Tema pokok kelompok dan sel Salafi ini adalah pemurnian Islam, yakni membersihkan Islam 
Nurul Faiqah, Toni Pransiska; Radikalisme Islam Vs Moderasi Islam: Upaya Membangun Wajah Islam Indonesia yang Damai.

\begin{abstract}
dari pemahaman dan praktek keagamaan yang mereka pandang sebagai 'bid'ah', yang tidak jarang mereka lakukan dengan caracara kekerasan. Dengan pemahaman dan praksis keagamaan seperti itu, kelompok dan sel radikal ini 'menyempal' (splinter) dari mainstream Islam yang memegang dominasi dan hegemoni otoritas teologis dan hukum agama dan sekaligus kepemimpinan agama. Karena itu, respon dan reaksi keras sering muncul dari kelompokkelompok 'mainstream', arus utama, dalam agama. Mereka tidak jarang mengeluarkan ketetapan, bahkan fatwa, yang menetapkan kelompokkelompok sempalan tersebut sebagai sesat dan menyesatkan. Ketetapan atau fatwa tersebut dalam prakteknya tidak jarang pula digunakan kelompokkelompok mainstream tertentu sebagai dasar dan justifikasi untuk melakukan tindakan main hakim sendiri.
\end{abstract}

3. Deprivasi politik, sosial dan ekonomi yang masih bertahan dalam masyarakat. Pada saat yang sama, disorientasi dan dislokasi sosial-budaya, dan ekses globalisasi, dan semacamnya sekaligus merupakan tambahan faktor-faktor penting bagi kemunculan kelompok-kelompok radikal. Kelompok-kelompok sempalan tersebut tidak jarang mengambil bentuk kultus (cult), yang sangat eksklusif, tertutup dan berpusat pada seseorang yang dipandang kharismatik. Kelompok-kelompok ini dengan dogma eskatologis tertentu bahkan memandang dunia sudah menjelang akhir zaman dan kiamat; sekarang waktunya bertobat melalui pemimpin dan kelompok mereka. Doktrin dan pandangan teologiseskatologis seperti ini, tidak bisa lain dengan segera dapat menimbulkan reaksi dari agama-agama mainstream, yang dapat berujung pada konflik sosial. Munip (2012:165) menjelaskan bahwa Radikalisme keagamaan jelas berujung pada peningkatan konflik sosial dan kekerasan bernuansa intra dan antar agama; juga bahkan antar umat beragama dengan negara. Ini terlihat jelas, misalnya, dengan meningkatnya aktivitas penutupan gereja di beberapa tempat dimana kaum Muslim mayoritas, seperti di Bekasi, Bogor dan Temanggung belum lama ini. Atau penutupan masjid/mushala di daerah mayoritas non-Muslim diberbagai tempat di tanah air, seperti di Bali pasca bom 
Bali Oktober 2002; termasuk pula anarkisme terhadap berbagai fasilitas dan masjidmasjid Ahmadiyah serta para jemaatnya. Berbagai tindak kekerasan terhadap pengikut Ahmadiyah juga masih terus terjadi di sejumlah tempat mulai dari NTB, Parung, Cikeusik dan berbagai lokasi lain. Lalu ada juga kelompokkelompok hardliners atau garis keras di kalangan muslim, menegakkan hukumnya sendiri-atas nama syari'ah (hukum Islam)seperti pernah dilakukan Lasykar Jihad di Ambon ketika terjadinya konflik komunal Kristen-Muslim; atau razia-razia yang dilakukan Front Pembela Islam (FPI) dalam beberapa tahun terakhir ini, khususnya pada Ramadhan, atas diskotik, dan tempat-tempat hiburan lainnya atas nama alamr bial-ma'ruf wa al-nahy 'anal-munkar (menyeru dengan kebaikan dan mencegah kemungkaran). Bagi mereka tidak cukup hanya amar ma'ruf dengan lisan, perkataan; harus dilakukan pencegahan terhadap kemungkaran dengan tangan (al-yad), atau kekuatan. Sekalilagi, tindakan-tindakan seperti ini juga dapat memicu terjadinya konflik sosial. Umat Islam mainstream-seperti diwakili NU, Muhammadiyah, dan banyak organisasi lain- berulangkali menyatakan, mereka menolak cara-cara kekerasan, meski untuk menegakkan kebaikan dan mencegah kemungkaran sekalipun. Tetapi, seruan organisasi-organisasi

mainstream ini sering tidak efektif; apalagi di dalam organisasi-organisasi ini juga terdapat kelompok garis keras yang terus juga melakukan tekanan internal terhadap kepemimpinan organisasi masing-masing.

Fenomena radikalisme Islam diyakini oleh banyak pihak sebagai ciptaan abad ke-20 di dunia Muslim, terutama di Timur Tengah, sebagai produk dari krisis identitas yang berujung pada reaksi dan resistensi terhadap Barat yang melebarkan kolonialisasi di dunia Muslim. Terpecahnya dunia Muslim ke dalam berbagai negara bangsa (nationstate) dan proyek modernisasi yang dicanangkan oleh pemerintah baru berhaluan Barat mengakibatkan umat Islam merasakan mengikisnya ikatan agama dan moral yang selama ini mereka perpegangi secara kuat (Dekmejian, 1985: 2536) Hal ini menyebabkan munculnya gerakan-gerakan Islam radikal yang menyerukan kembali ke ajaran Islam yang murni sebagai jalan keluar. Tidak sampai disitu, gerakan ini melakukan perlawanan terhadap rezim yang dianggap sekuler dan menyimpang dari agama. Selain fundamentalisme Islam, ada berbagai istilah yang dipakai para pengamat dan sarjana untuk 
Nurul Faiqah, Toni Pransiska; Radikalisme Islam Vs Moderasi Islam: Upaya Membangun Wajah Islam Indonesia yang Damai.

mengidentifikasi dan menjelaskan fenomena kebangkitan Islam di dunia Muslim, antara lain: revivalisme, radikalisme, militansi, Islamisme, Islam politik (political Islam), skripturalisme, dan extrimisme. Dari berbagai istilah ini, fundamentalisme nampaknya lebih umum dipakai oleh media dan akademisi. Akan tetapi, tidak semua sarjana sepakat dengan istilah ini, karena mengandung makna pejoratif terhadap Islam.

Istilah lain yang populer dan penulis gunakan dalam artikel ini sebagai alat identifikasi ialah 'Islam radikal' atau 'radikalisme Islam'. Istilah ini bagi penulis tampak lebih netral dan kurang pejoratif, serta secara umum dipakai dalam disiplin ilmu politik dan sosiologi untuk menjelaskan fenomena social tertentu. Mengikuti definisi yang dibuat oleh Jamhari dan Jahroni (2004: 2-3), Islam radikal mengacu kepada "kelompok yang mempunyai keyakinan ideologis tinggi dan fanatik yang mereka perjuangkan untuk menggantikan tatanan nilai dan system yang sedang berlangsung." Dari perspektif ini, ada tiga kecenderungan umum radikalisme. Pertama, radikalisme merupakan respon terhadap kondisi yang sedang berlangsung. Biasanya respons tersebut muncul dalam bentuk evaluasi, penolakan atau bahkan perlawanan. Kedua, radikalisme tidak berhenti pada upaya penolakan, melainkan terus berupaya mengganti tatanan tersebut dengan suatu bentuk tatanan lain. Ketiga, kuatnya keyakinan kaum radikalis akan kebenaran program atau ideologi yang mereka bawa. Sikap ini pada saat yang sama dibarengi dengan penafian kebenaran sistem lain yang akan diganti (Bahtiar Effendy, 1998: 12-13).

Istilah terorisme sendiri baru populer pada tahun 1793 sebagai akibta revolusi Perancis, tepatnya ketika Robespierre mengumumkan era baru yang disebut dengan Reign of Terror (10 Maret 1793 - 27 Juli 1794). Teror menjadi agenda penting para pengawal revolusi dan menjadi keputusan pemerintah untuk mengukuhkan stabilitas politik, tetapi juga tokoh-tokoh moderat, pedagang, agamawan dan lain sebagainya. Selama berlangsung Revolusi Prancis, Robespierre dan yang sejalan dengannya seperti St. Just dan Couthon melancarkan kekerasan politik dengan membunuh 1366 penduduk Perancis, laki-laki dan perempuan, hanya dalam waktu 6 minggu akhir dari masa teror (Mihanna, 2003: 122).

Dalam kamus Oxford (1981: 736) kata Terorist diartikan dengan orang yang melakukan kekerasan terorganisir untuk mencapai tujuan politik tertentu. Aksinya disebut terorisme, yaitu penggunaan kekerasan dan kengerian atau ancaman, terutama untuk tujuantujuan politis. Sementara itu, fatwa MUI (2004: 80) tentang terorisme menyatakan bahwa Terorisme adalah tindakan kejahatan terhadap kemanusiaan dan peradaban yang menimbulkan ancaman serius terhadap kedaulatan negara, bahaya terhadap keamanan, perdamaian dunia serta merugikan 
kesejahteraan masyarakat. Terorisme adalah salah satu bentuk kejahatan yang diorganisasi dengan baik (wellorganized), bersifat transnasional dan digolongkan sebagai kejahatan luar biasa (extra-ordinary crime) yang tidak membedabedakan sasaran (indiskrimatif).

Organisasi-organisasi

Internasional seperti PBB, mendefinisikannya dengan salah satu bentuk kekerasan terorganisir. Bentuknya seperti disepakati masyarakat dunia dapat berupa pembunuhan, penyiksaan, penculikan, penyanderaan tawanan, peledakan bom, atau bahan peledak dan lainnya yang dapat menjadi pesan pelaku teror. Aksi tersebut biasanya untuk tujuan politik, yaitu memaksa kekuatan politik tertentu, negara atau kelompok agar mengambil kebijakan atau merubnya sesuai yang diinginkan pelaku (Ezzuddin, 1981: 89). Dalam sidang Umum ke 83, tanggal 8 Desember 1998, PBB mengecam segala bentuk kekerasan aksi teror dengan alasan apapun, termasuk yang bermotifkan politik, filsafat, akidah/ideologi, ras, agama, dan lainnya.

Secara umum, terorisme diartikan sebagai cara atau teknik intimidasi dengan sasaran sistematik, demi suatu kepentingan politik tertentu. Whittaker (2003) mengutp beberapa pengertian terorisme antara lain menurut Walter Reich yang menyatakan bahwa terorisme adalah a strategy of violence designed to promote desired outcomes by instilling fear in the public at large (suatu strategi kekerasan yang dirancang untuk meningkatkan hasil-hasil yang diinginkan, dengan cara menanamkan ketakutan di kalangan masyarakat umum). Sementara pihak mengartikan terorisme sebagai ...the deliberate, systemic, murder, maiming, and menacing of the innocent to inspire fear in order to gain political ends...terrorism is politically evil, necessarily evil and wholly evil (pembunuhan dengan sengaja yang direncanakan secara sistematik, sehingga mengakibatkan cacat dan merenggut atau mengancam jiwa orang yang tidak bersalah, sehingga menimbulkan ketakutan umum, semata-mata demi mncapai tujuan politik, terorisme adalah suatu kejahatan politik, yang dari segi apapun merupakan kejahatan dan dalam artian secara keseluruhan adalah merupakan kejahatan) (Poul Johnson, 2008: 189).

Akar terorisme global pada era ini adalah ideologi universal, bukan agama yang secara sangat sinis kerap dikaitkan dengan ideologi itu. Ideologi yang mendorong benturan, konflik, dan mempertajam fragmentasi budaya secara terusmenerus telah menumbuhkembangkan fundamentalisme. Tujuan para pelaku terorisme dan motivasinya di masa lalu sangatlah beragama, yaitu demi keuntungan ekonomi (gold), memperoleh gensi sosial (glory), memaksakan ideologi, penafsiran keyakinan atau eksploitasi agama, kebudayaan, hegemoni, kekuasaan, dominasi kultural, ataupun pemaksaan konsep falsafati. 
Nurul Faiqah, Toni Pransiska; Radikalisme Islam Vs Moderasi Islam: Upaya Membangun Wajah Islam Indonesia yang Damai.

Terorisme tidak mempunyai nilai, karena nilai dalam aksiologis terdiri atas etika (baik dan buruk), norma moral (salah dan benar), dan nilai estetika (elok dan tidak elok). Bahasa dalam terorisme adalah bahasa universal, yang penilaian terhadapnya juga bersifat universal. Oleh karena itu, nilai dari terorisme ternegasikan secara penuh oleh jatuhnya korban manusia yang tidak bersalah. Terorisme menggunakan suatu bahasa dalam mengungkan pikiran atau keyakinan pihak pelaku (subyek), yang menimbulkan panik dan ketakutan di kalangan masyarakat luas.

\section{GERAKAN ISLAM RADIKAL VS ISLAM MODERAT}

Willian E. Shepard membagi Islam ke dalam lima tipologi gerakan Islam, yaitu: sekularisme, modernisme Islam, Islam radikal, tradisionalisme, dan neotradisionalisme. Pandangan lain tentang tipologi gerakan Islam, dapat digolongkan menjadi: modernisme Islam, tradisionalisme Islam, fundamentalisme Islam, neomodernisme Islam, neofundamentalisme Islam sampai kepada yang belakangan ramai diperbincangkan orang di tanah air, yakni post tradisionalisme Islam.

Ada empat tipologi kelompok gerakan Islam yang dielaborasi Setara Institute. Pertarna, kelompok Islam moderat yang memiliki tiga ciri yaitu: (1) tidak menggunakan kekerasan dalam agenda perjuangan Islam; (2) akomodatif terhadap konsep negara-bangsa modern; (3) organisasi bersifat terbuka (contohnya NU dan Muhammadiyah). Kedua, kelompok Islam radikal transnasional yang memiliki empat ciri yaitu: (1) berjuang melakukan perubahan sistem sosial dan politik; (2) tidak menggunakan kekerasan dalam agenda perjuangan Islam; (3) perjuangannya bersifat ideologis; (4) organisasi bersifat terbuka dan lintas batas negara (contohnya $\mathrm{HTI}$ ). Ketiga, kelompok Islam radikal lokal yang memiliki empat ciri yaitu: (1) menggunakan kekerasan dalam agenda perjuangannya jika tidak terjadi perubahan di masyarakat; (2) tidak merencanakan pembunuhan; (3) perjuangannya ada yang bersifat pragmatis dan ideologis: (4) organisasi bersifat terbuka dan hanya ada di Indonesia (conlohnya FPI). Keempat, kelompok Islam jihadis yang memiliki empat ciri yaitu: (1) menggunakan kekerasan dalam agenda perjuangannya akibat ketidakadilan penguasa terhadap umat Islam; (2) mengguna-kan pengeboman sebagai strategi penyerangan, bahkan dalam beniuk bom bunuh diri; (3) organisasi bersifat tertutup (bawah tanah); (4) melakukan penyerangan terhadap aparatur negara (contohnya Jamaah Islamiyah). Penelitian ini lebih memfokuskan pada gerakan Islam radikal yang ada dan berkembang di Indonesia khususnya di Jawa Tengah.

Warna keberagamaan Islam yang "khas" masyarakat di Indonesia tengah mengalami gugatan dengan kehadiran fenomena radikalisme beberapa tahun terakhir ini. Pemahaman keagamaan 
mainstream yang dianut mayoritas umat Indonesia dinilai bukan merupakan pemahaman yang benar, karena berbeda dengan Islam yang ideal, Islam yang dicontohkan oleh salaf als-shalih. Radikalisme adalah gerakan yang memegang konservatif dan sering menggunakan kekerasan untuk mengajar keyakinan mereka (Harun, 1995: 124). Sementara Islam adalah agama damai yang mengajarkan sikap berdamai dan mencari perdamaian (Madjid, 1992: 260). Islam tidak membenarkan penggunaan kekerasan dalam menyebarkan praktek agama, afinitas agama dan keyakinan politik. Tapi tidak bisa dipungkiri bahwa dalam perjalanan sejarahnya ada kelompok Islam tertentu yang menggunakan kekerasan untuk mencapai tujuan politik atau mempertahankan memahami kaku agama bahwa bahasa peradaban global yang sering disebut radikalisme Islam (Bakri, 2004: 2).

Istilah Radikalisme untuk menggambarkan kelompok militan dianggap lebih tepat sebagai fundamentalisme itu sendiri. Dalam perspektif Barat Fundamentalisme berarti paham orang-orang kaku ekstrim serta tidak segan-segan berperilaku dengan kekerasan dalam mempertahankan ideologinya. Sementara dalam perspektif Islam, fundamentalisme berarti tadjid berdasarkan pesan moral Al-Qur'an dan as-Sunnah (Imarah, 1999: 22). Dalam tradisi pemikiran teologis fundamentalisme agama adalah gerakan untuk mengembalikan seluruh perilaku tatanan kehidupan umat Islam untuk Al-Quran dan AlHadits (Watt, 1998: 2). Sebutan fundamentalis memang terkadang bermaksud untuk menunjuk kepada kelompok pengembali (revivalis) Islam (Gibb, 1990: 52). Tapi kadangkadang istilah fundamentalis ini juga dimaksudkan untuk merujuk kepada radikalisme Islam. Sehingga peneliti lebih cenderung menggunakan radikalisme jangka fundamentalisme karena pemahaman fundamentalisme dapat memiliki arti lain kadang-kadang mengkaburkan dimaksudkan makna menjadi radikalisme terlihat lebih jelas makna yang ditunjuk adalah gerakan yang menggunakan kekerasan untuk mencapai target politik yang didukung oleh sentimen atau emosi keagamaan (Bakri, 2004: 3).

Nama untuk label untuk radikalisme kelompok militan Islam juga beragam seperti ekstrem kanan, fundamentalis, militan dan sebagainya. M.A. Shaban (1994: 56) mengacu ekstremisme kekerasan (radikalisme) sebagai neo-Khawarij. Sementara itu, Harun Nasution (1995: 125) sebut sebagai Khawarij abad kedua puluh (abad 21-pen) karena itu adalah jalan untuk mencapai tujuannya adalah untuk menggunakan kekerasan seperti yang dilakukan di Khawarij posting tahkim. Islam sebagai agama damai sebenarnya tidak membenarkan praktik kekerasan. cara radikal untuk mencapai tujuan politik atau mempertahankan apa yang dianggap suci tidak cara Islam. Dalam tradisi peradaban Islam itu sendiri juga tidak diketahui label radikalisme (Bakri, 2004: 4). 
Nurul Faiqah, Toni Pransiska; Radikalisme Islam Vs Moderasi Islam: Upaya Membangun Wajah Islam Indonesia yang Damai.

Radikalisme Islam berasal dari pers barat untuk menunjuk gerakan Islam garis keras (ekstrim, fundamentalis, militan). Radikalisme jangka adalah kode yang kadangkadang tidak dikenali dan kadangkadang secara eksplisit untuk Islam. Masalah di Barat, dan Amerika bukan Islam itu sendiri tetapi praktik kekerasan yang dilakukan oleh sekelompok komunitas Muslim dalam proses pembentukan identitas (jati diri) kelompok (Madjid, 1995: 270). Istilah fundamentalisme dan radikalisme dalam perspektif Barat sering dikaitkan dengan sikap ekstrim, kolot, stagnasi, konservatid, anti-Barat, dan sulit untuk berpendapat dan bahkan kekerasan fisik. Penggunaan radikalisme istilah atau fundamentalisme untuk Muslim tidak benar-benar tepat untuk radikalisme itu tidak terjadi di setiap negara Muslim dan tidak bisa disalahkan pada Islam. Radikalisme adalah gerakan yang dilakukan oleh individu atau kelompok yang dirugikan oleh fenomena sosialpolitik dan sosio-historis (Bakri, 2004: 4).

Gejala berlatih kekerasan oleh sekelompok Muslim yang, secara historis-sosiologis, lebih tepatnya sebagai gejala dari fenomena sosial-politik daripada agama meskipun dengan menaikkan bendera agama. Fenomena radikalisme yang dilakukan oleh beberapa Muslim, oleh pers Barat berlebihan, sehingga menjadi wacana internasional dan menciptakan opini publik bahwa Islam itu mengerikan dan penuh dengan kekerasan. Akibatnya tidak jarang image negatif banyak ditujukan kepada Islam sehingga umat Islam telah terpinggirkan sebagai orang yang perlu dicurigai.

Hal seperti itu terjadi karena masyarakat Barat mampu menguasai pers yang digunakan sebagai alat yang kuat untuk memproyeksikan budaya dominan peradaban global. Label Islam menyebutkan gerakan fundamentalis sangat menarik untuk pers Barat dari label Tamil di Sri Lanka, militan Hindu di India, IRA (kelompok bersenjata Irlandia Utara), militan sayap kanan psikoterapi sekte Yahudi, komunis-Marxis yang tidak jarang menggunakan kekerasan sebagai solusi pemecahan masalah (Bakri,2004: 5)

Realitas historis-sosiologis ini adalah bukti bagaimana Barat menggunakan standar ganda dan tidak adil untuk Islam. Masyarakat Barat memiliki klaim atas peradaban Islam sedangkan peradaban Islam dibentuk identitas. Dengan demikian tidak berarti membenarkan perilaku radikalisme Muslim dilakukan untuk alasan apa pun praktek kekerasan adalah pelanggaran norma agama serta pelecehan kemanusiaan.

Islam moderat lebih dikenal sebagai bentuk lawan dari Islam radikal atau dikenal dengan Islam garis tengah. Alasan utama dilahirkannya istilah Islam moderat oleh para pendirinya adalah karena adanya Islam garis keras tersebut. Maka Islam moderat ingin menjadi solusi atas hal-hal yang dipandang oleh sebagian orang sebagai bentuk dari garis keras tersebut. Istilah moderat (moderate) berasal dari 
bahasa Latin moderare yang artinya mengurangi atau mengontrol. Kamus The American Heritage Dictionary of the English Language mendefinisikan moderate sebagai: not excessive or extreme (tidak berlebihan dalam hal tertentu). Kesimpulan awal dari makna etimologi ini bahwa moderat mengandung makna obyektif dan tidak ekstrim, sehingga definisi akurat Islam Moderat adalah Nilainilai islam yang dibangun atas dasar pola pikir yang lurus dan pertengahan (l'tidal dan wasath).

Sebagai satu sistem ajaran dan nilai, sepanjang sejarahnya, Islam tidak menafikan kemungkinan mengambil istilah-istilah asing untuk diadopsi menjadi istilah baru dalam khazanah Islam. Tetapi, istilah baru itu harus benar-benar diberi makna baru, yang sesuai dengan Islam. Istilah itu tidak dibiarkan liar, seperti maknanya yang asli dalam agama atau peradaban lain. Kita sudah banyak mengambil istilah baru dalam Islam, seperti istilah "agama", "pahala", "dosa", "sorga", "neraka", yang berasal dari tradisi Hindu, tetapi kita berikan makna baru yang sesuai dengan konsep Islam. Dari peradaban Barat saat ini, kita mengambil banyak istilah, seperti istilah "worldview", "ideologi", dan sebagainya. Semua istilah bisa diadopsi, asalkan sudah mengalami proses adapsi (penyesuaian makna) dengan makna di dalam Islam, sehingga tidak menimbulkan kekacauan makna.

Menurut Dr Muhammad Imarah (2004: 145), Istilah wasathiyah termasuk yang sering disalah-artikan. Dalam bukunya, Ma'rakah al Mushthalahat bayna alGharb wa al-Islam (Perang Terminologi Islam versus Barat), Beliau menjelaskan dengan cukup panjang lebar makna konsep alwasathiyah di dalam Islam. Istilah alwasathiyah dalam pengertian Islam mencerminkan karakter dan jati diri yang khusus dimiliki oleh manhaj Islam dalam pemikiran dan kehidupan, dalam pandangan, pelaksanaan, dan penerapannya.

Islam moderat atau moderasi Islam adalah satu di antara banyak terminologi yang muncul dalam dunia pemikiran Islam terutama dalam dua dasawarsa belakangan ini, bahkan dapat dikatakan bahwa moderasi Islam merupakan isu abad ini. Term ini muncul ditengarai sebagai antitesis dari munculnya pemahaman radikal dalam memahami dan mengeksekusi ajaran atau pesan-pesan agama. Dengan demikian, memperbincangkan wacana moderasi Islam tidak pernah luput dari pembicaraan mengenai Radikalisme dalam Islam. Kalau kita merujuk kepada Alquran sebagai acuan ekspresi keberagamaan baik pada level pemahaman maupun penerapan, maka secara eksplisit ia menegaskan eksistensi umat moderat (Ummatan Wasathan)sebagai induk bagi pemahaman Islam atau seorang muslim moderat. Dengan demikian, semestinya eksistensi Islam moderat sebagai sebuah term tidak menjadi bahan perdebatan bagi kalangan muslim, namun nampaknya term ini tidak sedikit dari kelompok Islam 
Nurul Faiqah, Toni Pransiska; Radikalisme Islam Vs Moderasi Islam: Upaya Membangun Wajah Islam Indonesia yang Damai.

menolaknya, karena alasan-alasan tertentu, termasuk alasan bahwa term itu adalah produk negatif yang tendensius Barat dan karenanya harus ditolak. Islam moderat bagi kelompok ini harus ditolak karena pihak Barat memiliki pemaknaaan khusus tentangnya dan Barat kemudian memiliki ciri-ciri khusus bagi seseorang untuk layak dijuluki sebagai seorang muslim moderat.

Moderasi Islam adalah sebuah pandangan atau sikap yang selalu berusaha mengambil posisi tengah dari dua sikap yang berseberangan dan berlebihan sehingga salah satu dari kedua sikap yang dimaksud tidak mendominasi dalam pikiran dan sikap seseorang. Dengan kata lain seorang muslim moderat adalah muslim yang memberi setiap nilai atau aspek yang berseberangan bagian tertentu tidak lebih dari hak yang semestinya. Karena manusiasiapa pun ia-tidak mampu melepaskan dirinya dari pengaruh dan bias baik pengaruh tradisi, pikiran, keluarga, zaman dan tempatnya, maka ia tidak mungkin merepresentasikan atau mempersembahkan moderasi penuh dalam dunia nyata. Yang mampu melakukan hal itu adalah hanya Allah (al-Qaradhawi, 2007: 56).

ISLAM DAN MISI RAHMATAN LIL 'ALAMIN

Islam hadir di tanah Arab dengan misi memperbaiki tata kehidupan manusia menuju arah yang lebih baik, menegakkan hukum secara adil, memberangus segala bentuk penindasan dan menjamin kehidupan yang sejajar bagi seluruh umat manusia, apapun warna kulit dan latar belakang statusnya. Dalam kata lain, Islam adalah moralitas terbaik bagi umat manusia menuju kehidupan yang aman, damai dan sejahtera.

Moralitas Islam begitu nampak dalam berbagai ajaran, nilai, dan hukum yang tersurat dalam alQur;an dan hadits. Pada keduanya kita bisa menemukan berbagai kemuliaan Islam, keagungan hukum Allah sebagai satu-satunya aturan yang harus kita taati dan patuhi. Islam adalah berkah bagi seluruh manusia tanpa terkecuali. Kita mengetahui bahwa peran utama Nabi Muhammad Saw adalah pembawa perdamaian. Dengan demikian maka logikanya adalah bahwa pengikut Nabi Muhammad pun harus menjadi pelopor perdamaian. Hal itu perlu diungkapkan mengingat keberadaan sejumlah masyarakat kita, bangsa Indonesia ini bahkan di luar Indonesia yang mengaku dirinya sebagai pengikut Nabi Muhammad Saw, namun nyatanya telah terseret baik sadar maupun tidak ke dalam kancah yang merusak prinsip dan suasana damai. Diantara kegiatan tersebut adalah kekacuan, kerusuhan, anarkisme, pemboman di tempat umum dan rumah ibadah, unjuk rasa yang merusak dan bahkan menghilangkan nyawa, pungli, korupsi, kolusi, sogok, kronisme, dan nepotisme. Semua perilaku negatif ini telah menjadi akar penderitaan dan sangat merugikan bangsa kita. Lebih dari itu, ia telah merusak kehidupan 
damai yang kita semua cita-citakan dan perjuangkan. (Kemenag, 2014: 33).

\section{Islam Agama Damai}

Pesan Allah Swt, sebagai ajaran pokok yang diemban oleh Nabi Muhammad Saw untuk disampaikan kepada umat manusia adalah perdamaian (salām). Ini dibuktikan oleh kenyataan bahwa ajaran yang dibawakan beliau bukanlah dinamakan dengan Muhammadisme, Arabisme, Quraisyme atau isme-isme lainnya yang biasa disebarkan oleh pembesar-pembesar kaliber dunia. Ajaran yang beliau bawakan kepada umat manusia yang juga sampai kepada kita ini adalah islam, yang berarti selamat, sejahtera, tentram dan damai. Ini bermakna bahwa ajaran yang dibawakan beliau intinya damai. Dengan demikian siapapun yang mengatakan bahwa dirinya sedangkan mengembangkan ajaran Nabi Muhammad Saw yaitu Islam harus mengutamakan prinsip damai bukan sebaliknya. Prinsip damai ini harus tertuang dalam setiap langkah, mulai dari perencanaan sampai kepada pelaksanaan, dari sikap individu sampai kepada kebijakan negara, baik antara sesama atau antar bangsa yang lain.

Secara kelembagaan Nabi telah merumuskan beberapa fakta sejarah tentang membuat perdamaian dalam kebijakannya. Diantara yang terkenal adalah Perjanjian Hudaibiyah (bahkan dua termin), sampai kepada Piagam Madinah yang mencakup seluruh elemen masyarakat, dan kemudian menjalankannya dengan setia.
Sejumlah ayat dan hadits telah mengungkapkannya dengan jelas dan gamblang. Oleh karena itu, kalau ada kegiatan yang nyata-nyata merusak kedamaian, siapapun yang melakukannya atau apapun alasannya sudah pasti itu bukan bersumber dari ajaran islam. Sangat mungkin itu adalah ekspresi emosi seseorang atau kelompok yang mengatasnamakan Islam, karena ia bertentangan dengan misi Nabi Muhammad Saw yang sebenarnya membawa perdamaian dan kesejahteraan.

Oleh karean itu, sejumlah prinsip dan kegiatan lain yang beliau lakukan ditujukan untuk mendukung damai, mendukung Islam antara lain pemaaf, kerja keras, toleransi, jujur, tidak ada diskriminasi, setia kawan, tidak putus asa, berorientasi ke depan (futuristik), penuh perhitungan, tegas, tata aturan dan sistem, patuh hukum, sayang kepada yang lebih muda, hormat kepada yang lebih tua, dan sebagainya. Semua itu, adalah prinsip dan kebijakan yang dimaksudkan untuk menunjang tercipta dan terpeliharanya kedamaian untuk seluruh umat manusia sebagai inti misi kerasulan yang beliau emban.

\section{Islam Mengajarkan Toleransi}

Toleransi atau tasāmuh adalah di antara perilaku dan misi Nabi Muhammad Saw kepada umat manusia. Toleransi ini telah dipraktikkan dan kemudian dipromosikan dimana dan kapan saja. Sikap toleransi berarti juga tanpa memaksakan kehendak pribadi atas orang lain. Toleransi ini 
Nurul Faiqah, Toni Pransiska; Radikalisme Islam Vs Moderasi Islam: Upaya Membangun Wajah Islam Indonesia yang Damai.

dianjurkan dalam segala bidang kehidupan, terutama sekali dalam bidang kehidupan keagamaan. Toleransi bukanlah tukar menukar atau jual beli antara satu dengan yang lainnya. Tetapi ia sebagai sikap menghormati dan memberi peluang kepada orang lain untuk berpendapat, bersikap, dan bahkan berbuat yang mungkin tidak sesuai dengan apa yang kita pahami atau anut, sejauh tidak menyalahi hukum yang berlaku. Allah berfirman; "Untukmu agamamu, dan untukku agamaku"(Q.S. al-Kafirun: 6).

Ayat tersebut memberi pelajaran kepada kita bahwa betapa toleransi Nabi kepada orang di luar kelompoknya telah menjadi modal bagi perdamaian dunia. Bahwa toleransi adalah modal dalam melaksanakan dan memelihara suasana damai dalam skala yang lebih luas. Alangkah bahagianya kita sebagai sebuah bangsa besar Indonesia yang terdiri dari berbagai suku, bahasa, budaya, adat-isitiadat dan agama kalau dapat mengamalkan perilaku toleransi sebagaimana yang diajarkan oleh Nabi Muhammad Saw. Kita mengetahui ketik Nabi dan pengikutnya kembali ke Mekkah ketika segala kewenangan berada di tangannya, beliau tidak melakukan paksaan atas tradisi dan agama masyarakat, bahkan sikap toleransi lah yang ditunjukkan ketika itu. Masing-masing jamaah hidup berdampingan dan dalam naungan saling menghormati dan menghargai satu sama lainnya.

\section{MODEL MODERASI ISLAM ALA INDONESIA: PARADIGMA DAN AKSI}

Keragaman bahasa, budaya, dan agama yang menjadi identitas bangsa Indonesia, memiliki nilai strategis dalam kancah internasional. Sebagai bangsa yang multikutlur, multietnis dan multireligi ini adalah sebuah pertaruhan. Jika keragaman tersebut menjadi aspek penguat relasi sosial antar elemen bangsa, maka dunia akan melihat Indonesia sebagai rujukan utama sebagai ideal type (contoh ideal) dalam pengelolan keragaman.

Dalam skala internasional, posisi Indonesia sangat strategi dalam membangun perdamaian. Hal ini misalnya bisa kita lihat dari peran Indonesia dalam menengahi berbagai konflik di beberapa negara di Timur Tengah. Sejak dahulu Indonesia telah mengirimkan beberapa kontingen Garuda untuk menjadi penjaga perdamaian. Seperti di Bosnia, Sudan, dan Lebanon. Banyaknya harapan dunia akan peran serta Indonesia dalam menengahi berbagai konflik, tidak lain disebabkan keberhasilan Indonesia dalam mengelola keragaman tersebut, baik dari aspek budaya, bahasa, dan bahkan agama. Indonesia dipandang berhasil membangun moderasi islam (wasathiyah al-islam).

Fakta moderasi Islam itu dibentuk oleh pergulatan sejarah Islam Indonesia yang cukup panjang. Muhammadiyah dan NU adalah dua organisasi Islam yang sudah malang-melintang dalam memperjuangkan bentuk-bentuk 
moderasi Islam, baik lewat institusi pendidikan yang mereka kelola maupun kiprah sosial-politikkeagamaan yang dimainkan. Oleh karena itu, kedua organisasi ini patut disebut sebagai dua institusi civil society yang amat penting bagi proses moderasi negeri ini. Muhammadiyah dan NU merupakan dua organisasi sosial-keagamaan yang berperan aktif dalam merawat dan menguatkan jaringan dan institusi-insitusi penyangga moderasi Islam, bahkan menjadikan Indonesia sebagai proyek percontohan toleransi bagi dunia luar (Kahar t.t.). Dikatakan pula, sebagai organisasi Islam terbesar di Indonesia, NU selama ini memainkan peran yang signifikan dalam mengusung ide-ide keislaman yang toleran dan damai (Hamid 2007, 28).

Muhammadiyah, misalnya, adalah suatu pergerakan sosialkeagamaan modern yang bertujuan untuk mengadaptasikan ajaranajaran Islam yang murni ke dalam kehidupan dunia modern Indonesia. Dalam usaha mencapai tujuan tersebut, gerakan ini secara luas telah mendapatkan inspirasi dari ideide pembaruan Syaikh Muhammad Abduh, yang mengobarkan semangat pembaruan pembersihan Islam dari daki-daki sejarah yang selama ini dianggap bagian tak terpisahkan dari Islam (A. Shihab 1997, 303-304).

Dalam sejarah kolonialisme di Indonesia, Muhammadiyah dapat disebut moderat, karena lebih menggunakan pendekatan pendidikan dan transformasi budaya. Karakter gerakan Muhammadiyah terlihat sangat moderat, terlebih jika dibandingkan dengan gerakan Islam yang menggunakan kekerasan dalam perjuangan mengusir penjajah, sebagaimana ditunjukkan oleh gerakan-gerakan kelompok tarekat yang melakukan pemberontakan dengan kekerasan. Dalam perjalanan sejarah selanjutnya, NU dan Muhammadiyah adalah organisasi Islam yang paling produktif membangun dialog di kalangan internal masyarakat Islam, dengan tujuan membendung gelombang radikalisme. Dengan demikian, agenda Islam moderat tidak bisa dilepas dari upaya membangun kesalingpahaman (mutual understanding) antarperadaban (Basya 2013).

Sikap moderasi Muhammadiyah sebenarnya sejak awal telah dibangun oleh pendiri organisasi ini, yaitu K.H. Ahmad Dahlan. Dikatakan, salah satu pelajaran yang paling penting dari kepemimpinan Ahmad Dahlan adalah komitmen kuatnya kepada sikap moderat dan toleransi beragama. Selama kepemimpinannya dapat terlihat adanya kerja sama kreatif dan harmonis dengan hampir semua kelompok masyarakat. Bahkan, dengan rekan Kristennya, beliau mampu mengilhami rasa hormat dan kekaguman. Contoh yang paling menarik dari kemampuan K.H. Ahmad Dahlan adalah mengikat persahabatan erat dengan banyak pemuka agama Kristen. Kenyataan bahwa beliau dikenal sebagai orang yang toleran terhadap kaum misionaris Kristen akan tetapi tidak 
Nurul Faiqah, Toni Pransiska; Radikalisme Islam Vs Moderasi Islam: Upaya Membangun Wajah Islam Indonesia yang Damai.

berarti lantas beliau mengkompromikan prinsipprinsipnya. Dia adalah seorang praktisi dialog antaragama yang sejati, dalam pengertian dia mendengar apa yang dikatakan dan memerhatikan apa yang tersirat di balik kata yang diucapkan (A. Shihab 1997, 311-312). Dalam perkembangan lebih lanjut, Syafi'i mencatat, bahwa:

"Gerakan modernis itu, terutama Muhammadiyah semakin mempertimbangkan dimensi kultural dalam gerak dakwahnya sehingga terasa menjadi lebih lentur tanpa kehilangan prinsip dan misi utamanya. Persis dan AlIrsyad tetap bertahan, tetapi tidak pernah mengikuti mitranya Muhammadiyah yang terus berekspansi" (Ma'arif 2009, 62).

Sementara itu, sikap moderasi NU pada dasarnya tidak terlepas dari akidah Ahlusunnah waljama'ah (Aswaja) yang dapat digolongkan paham moderat. Dalam Anggaran Dasar NU dikatakan, bahwa NU sebagai Jam'iyah Diniyah Islamiyah berakidah Islam menurut paham Ahlussunah waljamaah dengan mengakui mazhab empat, yaitu Hanafi, Maliki, Syafi'i, dan Hambali. Penjabaran secara terperinci, bahwa dalam bidang akidah, NU mengikuti paham Ahlussunah waljamaah yang dipelopori oleh Imam Abu Hasan alAsy'ari, dan Imam Abu Mansyur alMaturidi. Dalam bidang fikih, NU mengikuti jalan pendekatan (almazhab) dari Mazhab Abu Hanifah
al-Nu'man, Imam Malik ibn Anas, Imam Muhammad ibn Idris al-Syafi'i, dan Ahmad ibn Hanbali. Dalam bidang tasawuf mengikuti antara lain Imam Junaid al-Bagdadi dan Imam Ghazali, serta imam-imam yang lain (Qomar 2002, 62).

Perkataan

Ahlusunnah

waljama'ah dapat diartikan sebagai "para pengikut tradisi Nabi Muhammad dan ijmak (kesepakatan) ulama". Sementara itu, watak moderat (tawassuth) merupakan ciri Ahlussunah waljamaah yang paling menonjol, di samping juga i'tidal (bersikap adil), tawazun (bersikap seimbang), dan tasamuh (bersikap toleran), sehingga ia menolak segala bentuk tindakan dan pemikiran yag ekstrem (tatharruf) yang dapat melahirkan penyimpangan dan penyelewengan dari ajaran Islam. Dalam pemikiran keagamaan, juga dikembangkan keseimbangan (jalan tengah) antara penggunaan wahyu (naqliyah) dan rasio ('aqliyah) sehingga dimungkinkan dapat terjadi akomodatif terhadap perubahanperubahan di masyarakat sepanjang tidak melawan doktrin-doktrin yang dogmatis. Masih sebagai konsekuensinya terhadap sikap moderat, Ahlussunah waljamaah juga memiliki sikap-sikap yang lebih toleran terhadap tradisi dibanding dengan paham kelompok-kelompok Islam lainnya. Bagi Ahlussunah, mempertahankan tradisi memiliki makna penting dalam kehidupan keagamaan. Suatu tradisi tidak langsung dihapus seluruhnya, juga tidak diterima seluruhnya, tetapi berusaha secara bertahap di- 
Islamisasi (diisi dengan nilai-nilai Islam) (Dhofier 1994, 148).

Pemikiran Aswaja sangat toleransi terhadap pluralisme pemikiran. Berbagai pikiran yang tumbuh dalam masyarakat muslim mendapatkan pengakuan yang apresiatif. Dalam hal ini Aswaja sangat responsif terhadap hasil pemikiran berbagai mazhab, bukan saja yang masih eksis di tengahtengah masyarakat (Mazhab Hanafi, Malik, Syafi'i, dan Hambali), melainkan juga terhadap mazhabmazhab yang lain seperti imam Daud al-Zhahiri, Imam Abdurrahman al-Auza'i, Imam Sufyan al- Tsauri, dan lain-lain (Muhammad 1999).

Model keberagamaan NU, sebagaimana disebutkan, mungkin tepat apabila dikatakan sebagai pewaris para wali di Indonesia. Diketahui, usaha para wali untuk menggunakan berbagai unsur nonIslam merupakan suatu pendekatan yang bijak. Bukankah Alquran menganjurkan sebuah metode yang bijaksana, yaitu "serulah manusia pada jalan Tuhanmu dengan hikmah dan nasihat yag baik (16:125) (Mas'ud 2004, 9). Dalam mendinamiskan perkembangan masyarakat, kalangan NU selalu menghargai budaya dan tradisi lokal. Metode mereka sesuai dengan ajaran Islam yang lebih toleran pada budaya lokal. Hal yang sama merupakan cara-cara persuasif yang dikembangkan Walisongo dalam mengislamkan pulau Jawa dan menggantikan kekuatan HinduBudha pada abad XVI dan XVII. Apa yang terjadi bukanlah sebuah intervensi, tetapi lebih merupakan sebuah akulturasi hidup berdampingan secara damai. Ini merupakan sebuah ekspresi dari "Islam kultural" atau "Islam moderat" yang di dalamnya ulama berperan sebagai agen perubahan sosial yang dipahami secara luas telah memelihara dan menghargai tradisi lokal dengan cara mensubordinasi budaya tersebut ke dalam nilai-nilai Islam (Mas'ud 2004, 10).

Moderasi Islam adalah jalan tengah di tengah keberagaman beragama. Wajah moderasi Islam nampak dalam hubungan harmoni antara islam dan kearifan lokal (local value). Local Value ini sebagai warisan budaya Nusantara, mampu disandingkan secara sejajar sehingga antara spirit islam dan kearifan budaya berjalan seiring, tidak saling menegasikan. Di sinilah wajah Islam Indonesia dipandang sangat tepat diterapkan dalam konteks heterogenitas budaya di kawasan ASEAN maupun dunia (Kemenag, 2014: 65)

Moderasi Islam juga berperan besar dalam mendialogkan Islam dan modernitas. Terhadap modernitas, Islam tidak dalam posisi menolak atau menerima secara menyeluruh, melainkan tetap mengedepankan sikap kritis sehingga modernitas tumbuh menjadi nilai positif ketimbang negatil. Di saat negara-negara muslim begitu kaku dan konservatif terhadap perubahan dan produkproduk modernitas, Indonesia justru menjadikannya media dakwah dengan memasukan spirit Islam di dalamnya (Zarkasyi, 2017). 
Nurul Faiqah, Toni Pransiska; Radikalisme Islam Vs Moderasi Islam: Upaya Membangun Wajah Islam Indonesia yang Damai.

Kini, di saat dunia terus berada dalam bayang-bayang benturan sosial, seperti yang terjadi di Afghanistan, Irak, Suriah, hingga Irlandia, Indonesia tampil dengan kebersamaan dalam keragaman. Sungguh sangat indah menyaksikan berbagai agama, budaya, dan suku hidup berdampingan, saling menghormati. Masing-masing daerah tidak lagi mengusung aura kedaerahan atau kesukuan, melainkan hidup rukun di bawah payung Pancasila dalam bingkai NKRI.

$\mathrm{KH}$. Hasyim Muzadi memiliki pandangan tersendiri tentang moderasi muslim Indonesia. Menurutnya, umat Islam Indonesia patut bangga karena memiliki cara berfikir keagamaan yang mengikuti ahlussunah yang diaplikasikan dalam kehidupan keindonesiaan yang menggabungkan antara ibadah, fikih, dan tasawuf secara bersamaan. Bangsa ini memiliki karakter keberagamaan yang taat, tanpa menghapus nilai kebangsaan. Umat Islam mampu hidup berdampingan dengan berbagai kelompok umat dan budaya lain, tanpa menanggalkan identitas keislamannya sesuai dengan ketentuan wahyu,

Umat Islam Indonesia memiliki seting pemikiran paradigma berfikir yang menempatkan nilai agama dan Negara hidup berdampingan, tidak saling menegasikan, serta tidak merusak kemajemukan. Bangsa Indonesia tidak tertarik untuk mendirikan negara sekuler, begitu pula dengan negara agama (daulah islamiyah).
Sekulerisme telah gagal membangun bangsa-bangsa di dunia, sebagaimana Negara agama juga tidak mampu membangun dalam kemajermukan. Tetapi Indonesia yang sangat majemuk dengan beragam budaya dan agama mampu hidup damai dan berdampingan. Ini adalah sebuah prestasi bahwa bangsa Indonesia berhasil membangun negara di atas prinsip agama dan budaya bangsa, tidak menegasikan satu atas yang lainnya. $\quad \mathrm{KH}$. Hasyim menggarisbawahi bahwa kondisi ini terbentuk bukan tanpa usaha. Para pendahulu telah membangun fondasi yang kokoh tentang keberagaman dan kebangsaan sebagai tonggak moderasi Islam, kita tinggal merumuskan saja dalam moderasi Islam.

Moderasi pemikiran yang dibangun para ulama dapat dimengerti oleh berbagai aliran, baik yang ekstrem maupun liberal. Moderasi pemikiran Islam menemukan tempatnya di Indonesia. Bahkan sekte-sekte sangat menghargai moderasi kita, sekalipun belum tentu mengikuti. Di dunia Islam pun garis moderasi ini bisa mengatasi modernisasi dan globalisasi, Ketika arus globalisasi dan informasi deras memasuki kehidupan masyarakat, moderasi Islam mampu menyikapinya dengan baik (Abdul A'la, 2008)

Di sinilah, agama harus dilepaskan dari politik kekuasaan, dan dijadikan alat justifikasi. Agama perlu dikembalikan kepada eksistensinya sebagai sumber moralitas luhur yang selalu 
membimbing umatnya dan umat manusia secara keseluruhan dalam seluruh aspek kehidupan mereka. Melalui, pendekatan moral, langit harapan akan tampak lebih cerah, Kekerasan tidak dihadapkan dengan kekerasan yang lain. justru, masingmasing pihak diharapkan akan kembali kepada eksistensinya sebagai manusia yang mengemban moralitas luhur dalam bentuk pembumian kedamaian, keadilan, kesetaraan dan sejenisnya, serta pengendallan diri dan lain seabagainya. Terlepas dari semua itu, bangsa Indonesia tetap harus berhati-hati, karena potensi konflik akan terus bermunculan, Dengan arus inforrnasi yang semakin deras dengan beragam informasi, tentunya ini harus kita waspadai. Namun di sisi lain, arus informasi juga bisa rnenjadi kekuatan yang akan menjadi unsur penting dalam menjaga keharmonisan kehidupan umat beragama. Di sinilah peran komunikasi publik menjadi sangat vital dalam mewujudkan keharmonisan dimaksud.

\section{MENGAWAL DAN MEMBUMIKAN VISI MODERASI ISLAM INDONESIA}

Indonesia merupakan negara yang berpenduduk mayoritas Muslim. Tetapi kondisi ini tidak menjadikan Indonesia sebagai negara agama. Konsensus yang telah terbangun adalah republik. Dengan demikian, negara dan masyarakat harus mengayomi dan melindungi keragaman agama. Perbedaan harus disikapi dan diterima sebagai sunnatullah.

Keragaman harus dijadikan sebagai ladang ibadah untuk berlombalomba dalam kebaikan. Sebagai umat Islam, kita memiliki tanggungjawab untuk turut serta menciptakan kondisi tentram dan damai. Dengan kondisi yang damai, sangat dimudahkan untuk mewujudkan kemaslahatan umat manusia. Di sisi lain, Islam dengan tegas menolak sikap terorisme, radikalisme, anarkisme, keberingasan, dan pengrusakan yang mengatasnamakan agama. Tidak lain, karena hal tersebut sangat bertentangan dengan nilainilai dan watak dasar Islam.

Kita sebagai kaum Muslim Indonesia yang menjadi mayoritas sangat mafhum bahwa Indonesia bukanlah negara agama, melainkan negara yang memiliki banyak agama serta suku bangsa. Pancasila sebagai pandangan hidup berbangsa dan bernegara juga mengambil intisari dari kitab suci alQur'an. Tokoh-tokoh pendiri bangsa, dengan berbagai latar belakang agama yang dianut telah bahu membahu berperan penting dalam mendirikan sebuah negara bernama Indonesia. Oleh karenanya, Indonesia bukanlah dimiliki oleh satu agama, tetapi dimiliki oleh semua agama.

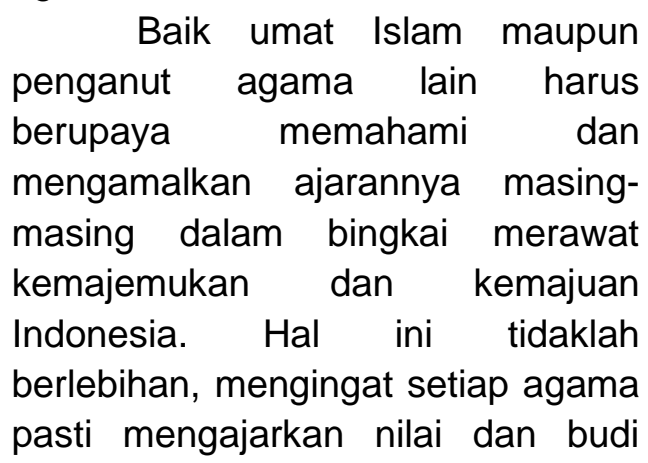


Nurul Faiqah, Toni Pransiska; Radikalisme Islam Vs Moderasi Islam: Upaya Membangun Wajah Islam Indonesia yang Damai.

luhur. Oleh karenanya, hidup damai dan toleran sudah semestinya menjadi komitmen bersama.

Al-Qur'an sebagai pedoman dan pegangan hidup Muslim, banyak menceritakan perihal sikap toleransi dan moderasi. Jika kita percaya pada isi serta kandungan al-Qur'an sebagai kitab toleransi semestinya kita memahami dan meresapi pesan-pesan toleransi yang terkandung di dalamnya. Selain itu, kita sebagai Muslim harus secara sadar dan aktif membumikan pesanpesan toleransi al-Qur'an pada kehidupan nyata. Ajaran cinta kasih merupakan ajaran yang mendasar dalam agama-agama samawi terdahulu. Apa yang disampaikan alQur'an, pada hakikatnya hendak menyempurnakan dan melanjutkan ajaran yang mulia tersebut. Karena itu, meletakkan toleransi sebagai nilai utama dalam keberagamaan umat Islam merupakan salah satu upaya menghadirkan sesuatu yang fundamental dalam Islam.

$$
\text { Dengan menguatnya }
$$

toleransi dan moderasi, masyarakat dan generasi muda tidak akan mudah untuk disusupi oleh doktrinasi gerakan-gerakan radikalisme, ektrimisme, dan terorisme. Bahkan sebaliknya, masyarakat akan menjadi tembok kokoh untuk menangkal gejala pendangkalan agama tersebut. Agama yang menjadi petunjuk manusia, tidak mungkin bisa diterima jika di dalamnya mengajarkan kekerasan dan kebengisan. Tidak lain karena, agama adalah cahaya dan petunjuk bagi keadaban dan peradaban.
Oleh karena itu, Sebagai kelompok terbesar umat Islam Indonesia, Muhammadiyah dan NU memiliki peran yang sangat menentukan. Sikap organisasi yang didirikan $\mathrm{KH}$ Ahmad Dahlan dan $\mathrm{KH}$ Hasyim Asy'ari -keduanya bersahabat-ini dinilai sangat penting bagi kalangan Islam Indonesia. Sebab, Muhammadiyah dan NU menjadi acuan sebagian besar umat Islam Indonesia, sehingga sikap keduanya ini sangat berpengaruh terhadap pikiran, perasaan, tindakan, dan perilaku sebagian besar umat Islam di Indonesia ini. Maka, Muhammadiyah dan NU memiliki kontribusi yang sangat besar dalam memengaruhi mereka, bahkan menjadi penentu mereka dalam menjalani kehidupan keagamaan sehari-hari.

Dalam menghadapi tindakantindakan radikal yang meresahkan masyarakat akibat ulah kalangan Islam fundamentalis, sebenarnya kita masih memiliki banyak harapan untuk membendung keberlangsungan radikalisme itu sepanjang Muhammadiyah dan NU solid dan sinergis menolaknya. Selama keduanya tak mendukung gagasan dan gerakan radikalisme, provokasi untuk melakukan teror tak efektif di Indonesia.

Kedua organisasi Islam terbesar di Indonesia ini memiliki cara-cara sendiri yang lebih persuasif dalam menjalankan misi perjuangannya dan sangat jauh dari pola-pola kekerasan. Cara-cara kekerasan dan radikal tidak akan pernah mampu menyelesaikan masalah di masyarakat, mengingat 
akan menimbulkan kekerasan lain sebagai pembalasan dendam atau kebencian yang membara di kalangan pihak-pihak yang dirugikan.

Penjagaan moderasi yang dilakukan Muhammadiyah dan NU tentu tidak akan menghalangi keduanya organisasi itu untuk bergerak secara dinamis. Keduanya tetap menjalankan agendanya masing-masing dan mengembangkannya secara aktif, dinamis, dan saling melengkapi. Jika peran itu tetap dilakukan kita optimis Indonesia tak akan menghadapi situasi buruk seperti di sejumlah negara-negara di Timur Tengah yang hari-harinya dipenuhi aksi-aksi kekerasan.

\section{PENUTUP}

Setiap agama-agama tidak terkecuali Islam tidak membenarkan bentuk aksi teror, kekerasan, atau apapun namanya yang mencederai nilai-nilai kemanusiaan, menyobek keharmonisan dan kerukunan antara sesama penganut agama maupun antar penganut agama. Bangsa ini dibangun diatas keragaman, dan kerukunan antar agama, budaya, bahasa dan lain sebagainya. Sehingga hal ini merupakan tantangan tersendiri bagi masyarakat Indonesia untuk membangun kedamaian, kerukunan dan kebersamaan. Realitas masyarakat Indonesia sekarang rawan akan terjadinya potensi konflik horizontal yang disebabkan faktor agama. Namun sejatinya konflik agama biasanya tidak murni disebabkan oleh faktor agama.
Tetapi, lebih non agama seperti kesenjangn sosial, ekonomi, politik dan lain sebagainya. Oleh karena itu, untuk menjaga potensi konflik di butuhkan dialog dan rumusan implementatif terkait teologi wasatiyyah islam (moderasi islam). Konsepsi dan implementasi Wasatiyyah Islam merupakan konsep utama yang terkait dengan ajaran islam dan pengalamannya untuk membentuk pribadi dan karakter muslim, konsep ini melekat dengn konsep ummatan wasathan. Visi moderasi Islam merupakan tawaran paradigma dan konsepsi yang ideal. Sebab, moderasi Islam tidak hanya terhenti dan se batas wacana dan paradigma semata, melainkan moderasi dapati mengejawantah dalam bentuk gerakan (movement). Nah, pilihan tujuan dari gerakan wasatiyyah islam dapat mengambil bentuk berupa gerakan kesadaran dari kelompok ekstrim kanan atau kiri Islam, atau pilihan gerakan alternatif sebagai counter opini baru dari dua kutub ekstrimitas islam. Namun yang tidak kalah penting lagi adalah perlu diformulasikan secara serius bagaimana fungsionalisasi wasatiyyah islam dalam praktek kehidupan bermasyarakat dan bernegara.

\section{DAFTAR PUSTAKA}
Abdul Munip,
Menangkal
Radikalisme Agama di Sekolah, Yogyakarta: Jurnal Pendidikan Islam, Volume I, Nomor 2, Desember 2012. 
Nurul Faiqah, Toni Pransiska; Radikalisme Islam Vs Moderasi Islam: Upaya Membangun Wajah Islam Indonesia yang Damai.

Abdurrahman Mas'ud, (2006), "Dari Haramain ke Nusantara : Jejak Intelektual Arsitek Pesantren", Jakarta: Kencana.

Abu Rokhmad, Radikalisme Islam dan Upaya Deradikalisasi Paham Radikal, Semarang: Walisongo, Volume 20, Nomor 1, Mei 2012.

Afdhal, Islam dan Radikalisme di Indonesia, Jakarta: LIPI Press, 2005

Ahmad Rubaidi, Radikalisme Islam, Nahdhatul Ulama: Masa Depan Modernisme Islam di Indonesia, Yogyakarta: Logung Pustaka, 2010.

Ahmad Zainul Hamid. "NU dalam Persinggungan Ideologi: Menimbang Ulng Moderasi Keislaman Nahdatul Ulama". Afkar, Edisi No. 21 Tahun 2007.

Alwi Shihab, Membendung Arus: Respons Gerakan Muhammadiyah terhadap Penetrasi Misi Kristen di Indonesia, Jakarta: Mizan, 1998.

Azyumardi Azra, Akar Radikalisme Keagamaan Perna Aparat Negara, Pemimpin Agama, dan Guru untuk Kerukunan Umat Beragama, Makalah disampaikan dalam workshop "Memperkuat Toleransi Melalui Institusi Sekolah", yang diselenggarakan oleh The Habibie Center, Tanggal 14 Mei 2011, Bogor.

Bahtiar Effendy dan Prasetyo, Hendro (eds.). Radikalisme
Islam , Jakarta: PPIMIAIN, 1998.

Dekmejian, R. Hrair. Islam in Revolution: Fundamentalism in the Arab World, New York: Syracuse University Press, 1985.

Ezzuddin, Al-Irhāb wa al-'Unf alSiyāsy, Cairo: Dār alHurriyah li al-Shahāfah wa alThibā'ah wa al-Nasyr, 1986.

Fatwa MUI, Terorisme, Jakarta: Fatwa MUI, Nomor 3 Tahun 2004.

H.A.R. Gibb, Aliran-Aliran Moderen Dalam Islam, Terjemahan Machnun Husein, Jakarta: Rajawali Press, 1990.

Harun Nasution, Islam Rasional, Bandung: Mizan, 1995.

Jajang Jahroni dan Jamhari. Gerakan Salafi Radikal di Indonesia, Jakarta: Rajawali Press, 2004.

Joyce M. Hawkins, Oxford Universal Dictionary, Oxford: Oxford University Press, 1981.

Kementerian Agama, Radikalisme Agam dan Tantangan Kebangsaan, Jakarta: Dirjen Bimbingan Masyarakat Islam, 2014.

M. Hilaly Basya, "Menelusuri Artikulasi Islam Moderat di Indonesia", http://www.madinask.com/ind ex.php?option=com, diakses tanggal 25 Mei 2018.

M. Zaki Mubarok, Genealogi Islam Radikal di Indonesia, Jakarta: LP3ES, 2008.

M.A. Shaban, Islamic History, Cambridge: Cambridge University Press, 1994 
Mambaul Ngadhimah, Potret Keberagamaan Islam Indonesia: Studi Pemetaan Pemikiran dan Gerakan Islam. Innovatio, Vol. VII, No. 14, Juli-Desember 2008.

Muhammad

Imarah, Fundamentalisme Dalam Perspektif Barat dan Islam, Terjemahan Abdul Hayyie alKattani, Jakarta: Gema Insani Press, 1999.

\section{Ma'rakah al}

Mushthalahat bayna al-

Gharb wa al-Islam, Cairo: Nahdah Misr, 2004.

Muhammad Mihanna, Al-Irhāb wa Azmat al-Qānūn al-Dauly alMu'āshir, dalam Al-Islām fi Muwājahat al-Irhābi, Cairo: Rābithah al-Jāmi'at alIslāmiyah, 2003.

Mujamil Qomar, NU Liberal; Dari Tradisionalisme Ahlusunnah ke Universalisme Islam, Bandung: Mizan, 2002.

Novriantoni Kahar, "Islam Indonesia Kini: Moderat Keluar, Ekstrem di Dalam?', diakses pada 25 Mei 2018.

Nurcholis Madjid, Islam Agama Peradaban, Mencari Makna Dan Relevansi Doktrin Islam Dalam Sejarah, Jakarta: Paramadina, 1995.

Menuju Tuhan, Jakarta:
Paramadina, 1995.
Paul Johnson, Heroes: From
Alexander the Great and
Julius Caesar to Churchill
and de Gaulle, tt: Prentice
Hall, 2008.

Pusat Bahasa Depdiknas RI, Kamus Besar Bahasa Indonesia, Jakarta: Pusat Bahasa Depdiknas, 2008.

R. Hrair Dekmejian. Islam in Revolution: Fundamentalism in the Arab World, New York: Syracuse University Press, 1985.

Ridwan al-Makasari, Masjid: Studi Kasus Jakarta dan Solo, Jakarta: UIN Jakarta, 2009.

Sri Yunanto, Gerakan Militan islam di indonesia dan Asia Tenggara, Jakarta: Ridep Institute, 2003.

Syamsul Bakri, "Islam dan Wacana Radikalisme Agama Kontemporer", Dinika, Vol 3. No. 1 Januari 2004.

Syamsul Rizal, Radikalisme Islam Klasik dan Komtemporer: Membanding Khawarij dan Hijbut Tahrir, Surabaya: AlFikr Volume 14 Nomor 2 Tahun 2010.

William Montgmery Watt, Islamic Fundamentalism And Nodernity, London: T.J. Press, 1998.

Willian E. Shepard, Islam dan Ideology: Towards a Typology, in Ab Anthology of Contemporary Middle Eastern History, Ed. Syafiq A. Mughni (Montreal: Canadian International Development Agency, 1988.

Yusuf al-Qaradhawi, Fiqh alwasa ìyah al-Islāmìyah wa-altajdīd : ma ālim wa-manārāt, Cairo: Dār al-Syurūq, 2010.

Zamakhsyari

Dhofier, Tradisi

Pesantren; Studi Tentang 
Nurul Faiqah, Toni Pransiska; Radikalisme Islam Vs Moderasi Islam: Upaya Membangun Wajah Islam Indonesia yang Damai.

Pandangan Hidup Kiai, Jakarta: LP3ES, 1994.

Zuhairi Misrawi, Pandangan Mislim Moderat, Jakarta: Kompas, 2010.

Zuly Qodir, Radikalisme Agama di Indonesia, Yogyakarta:

Pustaka Pelajar, 2014. 